\title{
REGENERATIVE PROCESS FOR DESULFURIZATION OF HIGH TEMPERATURE COMBUSTION AND FUEL GASES
}

\author{
QUARTERLY PROGRESS REPORT NO. 4 \\ JANUARY 1 - MARCH 31, 1977
}

PROCESS TECHNOLOGY DIVISION DEPARTMENT OF APPLIED SCIENCE

BROOKHAVEN NATIONAL LABORATORY ASSOCIATED UNIVERSITIES, INC.

UNITED STATES ENERGY RESEARCH AND DEVELOPMENT ADMINISTRATION

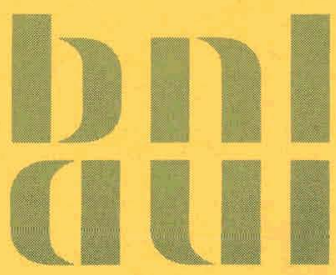




\section{DISCLAIMER}

This report was prepared as an account of work sponsored by an agency of the United States Government. Neither the United States Government nor any agency Thereof, nor any of their employees, makes any warranty, express or implied, or assumes any legal liability or responsibility for the accuracy, completeness, or usefulness of any information, apparatus, product, or process disclosed, or represents that its use would not infringe privately owned rights. Reference herein to any specific commercial product, process, or service by trade name, trademark, manufacturer, or otherwise does not necessarily constitute or imply its endorsement, recommendation, or favoring by the United States Government or any agency thereof. The views and opinions of authors expressed herein do not necessarily state or reflect those of the United States Government or any agency thereof. 


\section{DISCLAIMER}

Portions of this document may be illegible in electronic image products. Images are produced from the best available original document. 


\title{
REGENERATIVE PROCESS FOR DESULFURIZATION OF HIGH TEMPERATURE COMBUSTION AND FUEL GASES
}

\author{
QUARTERLY PROGRESS REPORT NO. 4 \\ JANUARY 1 - MARCH 31, 1977
}

Contributors:
A.S. Albanese
M-S. Shen
G. Farber
R. Smol
F.B. Kainz
M. Steinberg
J. Pruzansky
R.T. Yang

\author{
M. Steinberg, Head \\ R.T. YANG, Project Leader \\ PROCESS TECHNOLOGY DIVISION
}

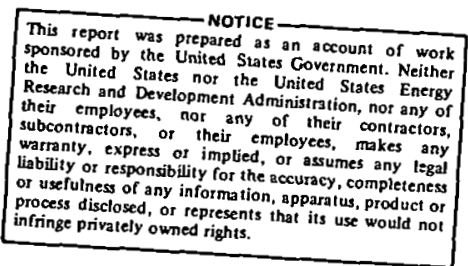

DEPARTMENT OF APPLIED SCIENCE 
NOT I C E

Thls report was priêpared as an account of work sponsored by the United Śtates Government. Neither the United States nor the United States Energy Research and Development Administration, nor any of their employees, nor any of their rontrartons, subcontractors, or their employees, makes any warranty, express or implied, or assumes

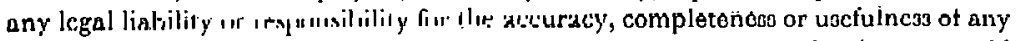
information, apparatus, product or process disclosed, or represents that its use would not infringe privately owned rights.

Printed in the United States of America Available from

National Technical Information Service

U.S. Department of Commerce

5285 Port Royal Road

Springfield, VA 22161

Price: Printed Copy $\$ 4 \$$, Microfiche $\$ 3.00$

June 1977

4.50

345 copies 
Table of Contents

page

Abstract . . iv

Introduction $\quad \ldots \quad \ldots$

Experimental : $\quad$.

Results and Discussion . . . . 3

A. Regeneration of CaO with Carbon 3

B. Sulfation and Regeneration of Calcium Silicates 5

C. Regeneration with Coal Ash Containing Unburnt Carbon 6

D. Catalytic Effect on Sulfation and Calcination 7

E. Materials Properties and Considerations 8

$\begin{array}{ll}\text { Process Design and Evaluation } & 10\end{array}$

$\begin{array}{lr}\text { Acknowledgement } & 12\end{array}$

References $\quad \cdot \cdot 12$

$\begin{array}{lr}\text { Tables } & 13\end{array}$

$\begin{array}{lr}\text { Figures } & 16\end{array}$ 


\section{Abstract}

Processes for regeneration of lime and lime-based sorbents to be used in fluidized-bed combustion (FBC) are being developed. Carbon, silica, and coal ash (which contains significant amounts of carbon and silica) are being investigated as the regeneration agents. Kilntype regenerators are being considered for the apparent solid=solid reactions involved in these processes. 


\section{Introduction}

The purpose of the Brookhaven program is to provide basic process chemistry information required for the development of processes for the utilization and regeneration of lime-based sorbents used in desulfurization of combustion and fuel gases for power production cycles.

Two basic processes for regeneration are currently under development. One is based on the reaction between $\mathrm{CaSC}_{4}$ and carbon for the regeneration of Cao. Another is being designed for regeneration and recycling of the calcium silicates as sorbents, with lime and siliceous matters as the starting materials. The basic reactions involved in the latter process are the formation of silicates from $\mathrm{CaSO}_{4}$ and $\mathrm{SiO}_{2}$ in the regeneration and the sulfation of the silicates in the combustor.

The two basic processes can be ideally combined in a third system by utilizing the fly ash. Fly ash from the FB combustor contains significant amounts of carbon; about 5-408 from the ANL and the Exxon fluidized bed pilot combustors. By feeding $\mathrm{fly}$ ash and sulfated limestone to a kilntype regenerator, calcium oxide and silicates are formed and are to be recycled to the combustor.

Kinetics and other relevant studies such as particle strength for fluidization and chemical analyses of the products for the three processes are being undertaken in parallel. TGA static systems as well as a micropilot system are being used for the kinetic studies. Process and cost analyses are also being made. These include material and energy balances and cost analysis with special attention to the regenerative processes being developed. Results of the studies will serve to guide future experimental work. 
In the course of a continuing search for catalytic effects in these processes, we found that sodium chloride showed significant positive effect. However, materials, environmental and corrosion problems from the chlorine compounds are also beịng considered.

\section{Experimental.}

In this report, the rates of regeneration and sulfation were obtained with THA reactors. $\Lambda$ Mettler TA-1, a LuPont 951 and a Cahn $R 100$ were installed with new. Tylan mass flowmeters for the measurements. The reactor systems and the experimental and calculation procedures have been described elsewhere. ${ }^{1-4}$ Chlorine content in the off-gas was analyzed by scrubbing in a caustic solution and the solution was subsequently analyzed colorimetrically, with a Technicon Auto Analyzer. Surface area was measured by a Micromeritics 2200 High Speed Surface Area Analyzer. Attrition was tested in a quartz tube fluidized with air for a certain period of time. A micro-pilot unit is under construction, which consists of a micro-rotary kiln as the regenerator (a screw feeder type reactor ic also being cunsldered) and a small (about 3-inch diameter) fluidized-bed combustor. Kinetics from this unit would provide a more realistic basis for designing the scale-up systems.

The sulfated limestnnos woxo cither a $30 z$ sulfated Greer limestone from a FBC at Argonne Nạtional Laboratory or the Greer stone which was calcined at $900^{\circ} \mathrm{C}$ in dry $\mathrm{N}_{2}$ and subsequently sulfated at $900^{\circ} \mathrm{C}$ with a gas containing $5 \% \mathrm{SO}_{2}$ ! $10 \% \mathrm{O}_{2}$ in dry $\mathrm{N}_{2} \cdot$ The calcination and sulfation were both carried out in static beds and the sulfation was $65 \%$ or $80 \%$ complete. Coal ash, silicates and carbon will be described in the. respective sections. The grades of the gases were the samc as those used previously. 
Results and Discussion

\section{A. Regeneration of CaO with carbon}

The calcium sulfate is reduced to $\mathrm{SO}_{2}$ by carbon:

$$
\mathrm{CaSO}_{4}+1 / 2 \mathrm{C} \rightarrow \mathrm{CaO}+1 / 2 \mathrm{CO}_{2}+\mathrm{SO}_{2}
$$

which is a two-step reaction:

$$
\begin{aligned}
& 1 / 4 \mathrm{CaSO}_{4}+1 / 2 \mathrm{C} \rightarrow 1 / 4 \mathrm{CaS}+1 / 2 \mathrm{CO}_{2} \\
& 1 / 4 \mathrm{CaS}+3 / 4 \mathrm{CaSO}_{4} \rightarrow \mathrm{CaO}+\mathrm{SO}_{2}
\end{aligned}
$$

Reaction 3 has also been discussed by Hubble et $a^{5}$ as a possible means for lime regeneration.

(I) Temperature Effect

It has been shown that reaction 2 is much faster than reaction

3 and that the amount of carbon is the controlling factor for determining the reaction product, i.e., CaO vs. Cas. The rate of reaction 3 controls the rate of regeneration of $\mathrm{CaO}$. The temperature dependence is presented in Arrhenius fashion in Fig. 1. It is recalled that a surface layer on the $\mathrm{CaSO}_{4}$ is first reduced rapidly by carbon via reaction 2 . The reduced layer then reacts with the remaining inner $\mathrm{CaSO}_{4}$ to form CaO via reaction 3. Two distinct slopes on the weight-time curves were obtained in the $\mathrm{CaSO}_{4}+1 / 2 \mathrm{C}$ reaction. The second slope was used to calculate the rates in Fig. 1. The rates here were based on the area of reacting interface, assuming the sulfated Greer limestone particles were perfect spheres. The temperature dependence shown in Fig. 1 is, however, accurate regardless whether this assumption was made, because the same amount of the same materials were used at each temperature.

The activation energy of reaction 3 is $62.7 \mathrm{kcal} / \mathrm{mole} \mathrm{CaO}$ which indicates a solid-phase diffusion and/or chemical reaction rate-limiting mechanism. 
This overall temperature dependence also means that the rate of regeneration of $\mathrm{CaO}$ is increased by a factor of three per $50^{\circ} \mathrm{C}$ rise in temperature in this temperature range.

(2) Effect of $\mathrm{NaCl}$ on Regeneration

The effects are demonstrated in Figs. 2 and 3. Figure 2 shows that 3\% $\mathrm{NaCl}$ (of $\mathrm{CaSO}_{4}$, by wt) catalyzes both reactions 2 and 3 , at $900{ }^{\circ} \mathrm{C}$. Figure 3 shows that at $900^{\circ} \mathrm{C}$, NaCl first catalyzes reaction 3 but very intriguingly, retards the reaction after about $35 \%$ regeneration. However, the results in Fig. 3 were with analytical reagent grade chemicals: As will be shown later, the retarding effect does not take place in the systems containing coal ash and limestone. Also in Fig. 3, the sizes were not specified. The samples were of A.R. grades powder. Figs. 4 and 5 show NaCl effect on regeneration at $850^{\circ} \mathrm{C}$ using the analytical reagent $\mathrm{CaSO}_{4}$ and Drierite $\left(99.6 \% \mathrm{CaSO}_{4}\right)$ respectively.

(3) Effect of the Size of Caso,

In the regeneration scheme, the size of the sulfated stone has to be suitable for fluidized-bed operation while the size of carhon ran be small. Figure 6 shows the integrated rates of the two stages (reactions 2 and 3) of the reactions between a partially sulfated Greer lime and coconut charcoal. The integrated rate was based on the total weight loss divided by the total time for each reaction. As shown in this figure, reaction 2 depends strongly on the size of the sulfated stone while reaction 3 has only a very slight dependence on the size. This is understandable because reaction 2 requires close contact between $\mathrm{CaSO}_{4}$ and $\mathrm{C}$ whereas reaction 3 does not, and the finer sizes of $\mathrm{CaSO}_{4}$ provide greater contacting areas. 


\section{B. Sulfation and Regeneration of Calcium Silicates}

The sulfation rates for $\mathrm{CaO}$ and $\mathrm{CaSiO}_{3}$ are compared in Figs. 7 to 11 as percent of completion for sulfation versus time (hours).

Figures 12 and 13 show that in all cases an increase in temperature increases the rate of sulfation. Also the extent of completion for calcined limestone $\mathrm{CaO}$ is higher in all cases, yet the initial chemical rates for CaO are in fact lower than $\mathrm{CaSiO}_{3}$.

Steam is shown in Figures 14 and 15 to be a catalyst in the rate of sulfation for both $\mathrm{CaO}$ and $\mathrm{CaSiO}_{3}$, as also found in the calculated rates for the initial chemical rates in Tables $A$ and $C$.

For calculations of the initial slopes (linear regression program) utilizing a Texas Instrument computing calculator Model SR-60, the initial chemical rates of $\mathrm{SO}_{3}$ uptake for both $\mathrm{CaO}$ and $\mathrm{CaSiO}_{3}$ were calculated. The results are found in Table $A$.

From the results in Table $A$, the initial chemical rate for calcium silicates reactivity to $\mathrm{SO}_{3}$ in flue gas conditions is greater in each case for temperatures $800^{\circ}-950^{\circ} \mathrm{C}$ and also in the case of steam addition. This increase is substantial (15-25\%) for the sulfation rate, based solely on mass and size for both $\mathrm{CaO}$ and $\mathrm{CaSiO}_{3}$ systems.

In Table $B$, the results for surface area measurements for 16/20 mesh $\mathrm{CaO}$ and $\mathrm{CaSiO}_{3}$ systems are given. The results are given as the average of two readings for each sample.

Based on the surface area measurements in Table $B$, the rates can thus be expressed as the amount of $\mathrm{sO}_{3}$ uptake for the total surface area available for both $\mathrm{CaO}$ and $\mathrm{CaSiO}_{3}$. The results in Table $\mathrm{C}$ for the rates are given as mole $\mathrm{SO}_{3} / \mathrm{cm}^{2} \mathrm{~min}$. Here the difference in rate based on 
available surface area is greatest. Calcium silicate sulfates at a rate of four times greater; still higher at higher temperatures.

\section{Regeneration with coal ash containing unburnt carbon}

This scheme represents the most practical and attractive process. Numerous experiments have been performed on this system, using partially sulfated Greer limestones from static beds and from Argonne's fluid bed, and coal ash contalning carbon that we generated at Brookhaven using small fluidized tubes and the fly ash from Exxon's Miniplant. Argonne's flyash will also be used shortly.

\section{(1) Rate of Regeneration}

Figure 16 shows the rate of regeneration of CaO from a $30 \%$ sulfated Greer limestone from Argonne's FBC and a coal ash (Ill. No. 6) containing 78 carbon, at $1000^{\circ} \mathrm{C}$. It is seen that more than $90 \%$ of the sulfated stone was regenerated within 20 minutes, and about $70 \%$ was regenerated in $7 \mathrm{~min}$. On the other hand, using the $65 \%$ sulfated Greer limestone and the same ash under identical, conditions, it took about 3 huurs for $30 \%$ regeneration at $900^{\circ} \mathrm{C}$. It appeared that the impurities in the $\mathrm{FBC}$ sample catalyzed the reaction greatly.

\section{(2) Reactivity of Regenerated Stone}

Figure 17 shows the sulfation rates of the first cycle and the second cycle after regeneration'with coal ash. Preliminary results indicate that there is no tendency for the reactivity of the regenerated stone to decay. Work in progress are physical and chemical properties of the regenerated stone.

(3) NaCl Effect

Rates of regeneration with and without $3 \%$ NaCl are shown in Fig. 18. Sodium chloride does catalyze the regeneration; more so in the initial 
stage of reaction 3 . It does not retard the reaction up to about $608 \mathrm{CaO}$.

(4) Effect of the Size of Coal Ash

Figure 19 shows the effect of the size of ash on rates of reactions 2 and 3. Both reactions are affected strongly by the size. It is not yet understood why reaction 3 has a stronger dependence on the size. The effcct of the carbon content in ash will be investigated.

(5) Reaction Product Analyses

Reactions were carried out between 850 and $1000^{\circ} \mathrm{C}$. The amount of ash (carbon content known) was controlled according to the stoichiometry of reaction 1. After each reaction, the ash was sieved out and the stone was analyzed by $\mathrm{x}$-ray diffraction.

The $x$-ray diffraction analyses to date show that CaO is the pre- : dominant product. Some CaS was detected. A trace of $\mathrm{CaSO}_{4}$ was also found. Some weak-intensity lines indicated the possibility of the existence of the calcium silicates. Our efforts now in this respect are to identify the silicates and to quantify them.

The $x$-ray results are consistent with the fact that the rates of reaction $l$ are higher than the rates of the reaction $\mathrm{CaSO}_{4}+\mathrm{SiO}_{4} \rightarrow \mathrm{CaO} \cdot \mathrm{SiO}_{2}+\mathrm{SO}_{2}+1 / 2 \mathrm{O}_{2}$. However, at the steady state in a continuous recycling process, the amounts of the silicates would be much higher because for each particle, as it is being recycled, contents of silicates would increase with the number of cycle. This is due to the fact that the silicates stay in the structure once formed.

D. Catalytic Effect of Sulfation and Calcination 


\section{(1) NaCl Effect on Sulfation}

With $3 \% \mathrm{NaCl}$ mixed in analytic reagent $\mathrm{CaO}$, sulfated with $0.25 \%$ $\mathrm{SO}_{2}, 58 \mathrm{O}_{2}$ and balance of $\mathrm{N}_{2}$ at different temperatures are shown in Figs. 20-23 and with $3 \% \mathrm{NaCl}$ mixed in Greer CaO shown in Fig. 24. The sulfation rate is increased by more than $100 \%$ below about $850^{\circ} \mathrm{C}$ and has an adverse effect above $900^{\circ} \mathrm{C}$.

(2) Steam Effect on Sulfation

The comparison of sulfation with and without $5 \%$ steam are shown in Fig. 21 (analytical reagent CaO), and Fig. 25 (Greer CaO). The combined effects of $5 \%$ steam and $3 \% \mathrm{NaCl}$ are also shown in the figures. Steam increases the sulfation rate, however, it is not clear why the combined effects of 'steam and $\mathrm{NaCl}$ are not additive.

(3) $\mathrm{Fe}_{2} \mathrm{O}_{3}$ Effect on Sulfation

$\mathrm{Fe}_{2} \mathrm{O}_{3}$ catalyzes sulfation. Figure 26 shows that $48 \mathrm{Fe}_{2} \mathrm{O}_{3}$ lof CaO, by wt) catalyzes sulfation at $850^{\circ} \mathrm{C}$. The size of $\mathrm{Fe}_{2} \mathrm{O}_{3}$ was not specified. Work is presently being done on the size and concentration effects of $\mathrm{Fe}_{2} \mathrm{O}_{3}$ on sulfation.

(4). NaCl Effect on Calcination

- NaCl catalyzes the calcination of limestone which is shown in Fig. 2\%

\section{E. Materials Properties and Considerations}

\section{(1) Attrition Test.}

The tests were designed for minute quantities of sample. The fluidizing material is a coarse sea sand. The sample which has a smaller size is sieved out after the test and its size analyzed. Table $C$ shows the results for Greer limestone (starting material), 65\% sulfated Greer limestone and first cycle regenerated stone. Preliminary results show 
that the strength of the regenerated sample depends on the amount of $\mathrm{CaSO}_{4}$ remaining. The residual $\mathrm{CaSO}_{4}$ as well as other impurities seem to strengthen the sample.

\section{(2) Surface Area}

Table $D$ shows the surface areas of several different materials. Before measuring the surface area, the materials were heated at $850^{\circ} \mathrm{C}$ for 2 hours in $\mathrm{N}_{2}$ flow. In calcining the Greer $\mathrm{CaCO}_{3}$ at $850^{\circ} \mathrm{C}, 38 \mathrm{NaCl}$ decreases the surface area of the CaO. In sulfation, $38 \mathrm{NaCl}$ mixed in the CaO also decreases the surface area. In regeneration (the decomposition of $\left.\mathrm{CaSO}_{4}\right), 3 \% \mathrm{NaCl}$ decreases the surface area of the $\mathrm{CaSO}_{4}$ too. However, the calcination, sulfation and regeneration rates are increased with 38 NaCl addition. This rules out the proposition that the effect of Nacl increased the surface area and hence increased the rate. It is possible that the sodium ion serves as a fluxing material thereby decreases the surface areas.

(3) Mechanism and Fate of $\mathrm{NaCl}$ in Sulfation and Regeneration

The fate of $\mathrm{NaCl}$ in $\mathrm{FBC}$ is being studied under simulated combustion conditions in static beds. With $3 \% \mathrm{NaCl}$ mixed in CaO, sulfated with $0.258 \mathrm{SO}_{2}, 58 \mathrm{O}_{2}, 5 \%$ steam and the balance of $\mathrm{N}_{2}$, the total chlorine. was collected by bubbling the off-gas through $\mathrm{NH}_{4} \mathrm{OH}$ or $\mathrm{NaOH}$ solution for a certain period of time. The chlorine was converted into chloride. The chloride is determined via formation of the ferric-thiocyanate complex. It reacts with undissociated mercuric thiocyanate to release an equivalent amount of thiocyanate ion. This immediately reacts with the ferric ion present to form the red-brown complex, which is measured at $480 \mathrm{~m} \mu$. Preliminary results show that high percentages of the chlorine in Nacl. 
were collected and that the higher the temperature, the higher percentage collected. More careful work is progressing in analyzing and quantifying the chlorine compounds under various conditions.

In the pilot-scale studies at PER, it has been indicated ${ }^{6}$ that no additional amount of $\mathrm{HCl}$ was detected in the $\mathrm{FBC}$ off-gas with $\mathrm{NaCl}$ in bed (the normal level being $40 \mathrm{ppm}$ ). In light of our observations, it is suggested that the additional chlorine compounds from the added $\mathrm{NaCl}$ may react with and deposit on the walls in FBr. which are primarily metals and metal oxides.

\section{E. Process Design and Evaluation}

Two process flow diagrams were prepared based on the best available data on FBC's, one for a once through sorbent, carbon burn-off cell system (System I); the other, for a regenerative sorbent system based on BNL's carbon reduction of $\mathrm{CaSO}_{4}$ process (System II). The feed to both systems was assumed to be Illinois No. 6 coal with a sulfur content of 3 weight percent and both systems were assumed to nperate al aluuwpherlc pressure.

Based on mass and energy balance calculations, it appears that the net energy output of System I (once through) is equal to that of System II (regenerative). However, the quantity of limestone feed required to satisfy the material balance of System I is appreciably greater than that required by system II. For a $200 \mathrm{MW}(e)$ power plant operating at a cycle efficiency of $40 \%$, these quantities are 18.752 tons/hr versus 1.312 tons $/ \mathrm{hr}$, respectively. At $\$ 12 /$ ton of limestone (including the cost of calcium sulfate disposal) this amounts to $\$ 1,971,000 /$ year for the once through system, and $\$ 138,000 /$ year for the regenerative system (assuming that total system attrition losses are equal to $7 \%$ of the 
total calcium feed to the FBC at 2.5 moles $\mathrm{Ca} /$ mole $\mathrm{S}$ ). Furthermore, it does not appear that the costs of the additional equipment items required by the regenerative system will offset this savings in operating costs. Thus, we anticipate that the regenerative system will be economically more attractive than the once through system. A more definitive economic analysis will be made during the next several months which will include an analysis of means of converting the $\mathrm{SO}_{2}$ contained in the regenerator gaseous effluent to sulfuric acid and to elemental sulfur.

From an operating standpoint, the regenerative system also appears more attractive than the once through system. Some of the advantages are as follows:

1). Limestone feed to the FBC (makeup in the case of the regenerative system) would not have to be controlled as carefully (in proportion to coal feed) as in the once through system because most of the calcium sorbent is recycled at an essentially constant rate. Maintaining an acceptable $\mathrm{SO}_{2}$ emission level would thus be facilitated.

2) The regenerative system is not as cost sensitive to calcium to sulfur ratio as is the once through system.

3) For the same calcium to sulfur ratio and assuming that $80 \%$ of the feed $\mathrm{CaCO}_{3}$ is calcined to $\mathrm{CaO}$ in the $\mathrm{FBC}$, a greater portion of the calcium would be present as $\mathrm{CaO}$ (less as $\mathrm{CaCO}_{3}$ ) which is the reaction with $\mathrm{SO}_{2}$. Reductions in $\mathrm{Ca} / \mathrm{S}$ may be realizable. 
Acknowledgement

Suggestions and discussions with Dr. Andrej Macek of ERDA are particularly

helpful. Discussions with Drs. A. A. Jonke, G. J. Vogel and W. M. Swift of

Argonne National Laboratory are also acknowledged.

\section{References}

1. M. Steinberg et al., "Regenerative Process for Desulfurization of High Temperature Combustion and Fuel Gases", Quarterly Reports Nos. 1 to 3, Brookhaven National Laboratory (1976).

2. R. T. Yang and M. Steinberg, Carbon, 13, 411 (1975).

3. R. T. Yang and M. Steinberg; J. Phys. Chem., 80, 965 (1976).

4. R. T. Yang, P. T. Cunningham, I. Wilson, and S. Johnson, Adv. Chem. Series, 137, 149 (1974).

5. B. R. Hubble, S. Siegel, and P. T. Cunningham, APCA Journal, 25, 1256 (1975).

6. M. Pope, "Pilot and Research Plants: A Progress Report", in Proc. Fourth Intern. Conf. Fluidized-Bed Combustion, Sponsored bY US ERDA, Coord. MITRE, Dec., 1975. 
Table A

Rates of Sulfation of Greer Limestone and Calcium Silicate in Simulated Flue Gas Conditions $\left(0.258 \mathrm{SO}_{2}, 58 \mathrm{O}_{2}, 94.758 \mathrm{~N}_{2}\right) \quad$ (z/min)
Temp. , ${ }^{\circ} \mathrm{C}$
$\mathrm{CaO}$
$\mathrm{CaSiO}_{3}$
800
$0.25 \pm 0.02$
$0.30 \pm 0.02$
850
$0.25 \pm 0.02$
$0.31 \pm 0.02$
900
$0.26 \pm 0.03$
$0.32 \pm 0.01$
900
$0.27 \pm 0.01^{a}$
$0.35 \pm 0.03^{b}$
950
$0.27 \pm 0.01$
$0.36 \pm 0.02$

\footnotetext{
$a_{4.5}$ percent steam

$b_{3.5}$ percent steam
}

Table B

Surface Area Measurements $\left(\mathrm{m}^{2} / \mathrm{g}\right)$ of Calcined Greer Limestone and Calcium Silicate
Temp. , ${ }^{\circ} \mathrm{C}$
$\mathrm{CaO}$
$\mathrm{CaSiO}_{3}$
800
$2.68 \pm 0.01$
$0.49 \pm 0.01$
850
$2.56 \pm 0.06$
$0.31 \pm 0.02$
900
$2.18 \pm 0.04$
$0.29 \pm 0.02$
950
$1.36 \pm 0.05$
$0.27 \pm 0.06$ 
Table C

Rates of Sulfation of Greer Limestone and Calcium silicate in Flue Gas Conditions $\left(0.258 \mathrm{SO}_{2}, 5 \% \mathrm{O}_{2}, 94.758 \mathrm{~N}_{2}\right)\left(\mathrm{mole} / \mathrm{cm}^{2} \mathrm{~min}.\right)$

Temp. ${ }^{\circ} \mathrm{C}$

$\mathrm{CaO}$

$1.2 \pm 0.1 \times 10^{-9}$

$1.2 \pm 0.1$

$1.5+0.1$

$1.6 \pm 0.1^{a}$

$2.5+0.2$
$\mathrm{CaSiO}_{3}$

$4.8 \pm 0.4 \times 10^{-9}$

$8.7 \pm 0.8$

$\dot{y} \pm 1$

$9.9^{b}$

$10^{\star} \pm 2$

$a_{4.5}$ percent steam

$b_{3.5}$ percent steam

* error large due to large error for small surface area measurement

Tablé $D$

nttrition Test

One gram samplè $(16 / 20 \mathrm{mesh})$ and $200 \mathrm{~g}$ sea sand $(4 / 8 \mathrm{mesh})$ in a J in. diunicter qualtz lube fluldized with $18.5 \mathrm{cu} \mathrm{ft} / \mathrm{min}$ air flow at room temperature for 18 hours. The air distributor was a fritted quartz plate.

\begin{tabular}{|c|c|c|c|c|}
\hline Sample/size (mesh) & $16 / 20$ & $20 / 24$ & $>24$ & $\begin{array}{l}\text { Blown away } \\
\text { as dust }\end{array}$ \\
\hline Greer limestone & 4.58 & 77.18 & 0.28 & 18.28 \\
\hline${\text { Greer } \operatorname{rnan}_{4}(65 *)}$ & 64.4 & $19 . \overline{7}$ & $1 . j$ & 14.2 \\
\hline $\begin{array}{l}\text { lst cycle regenerated } \\
\text { Greer limestone }\end{array}$ & 43 & 10.2 & 1.8 & 45 \\
\hline
\end{tabular}


Table E

Surface Area

Material

Treatment

Surfące Area

(16/20 mesh)

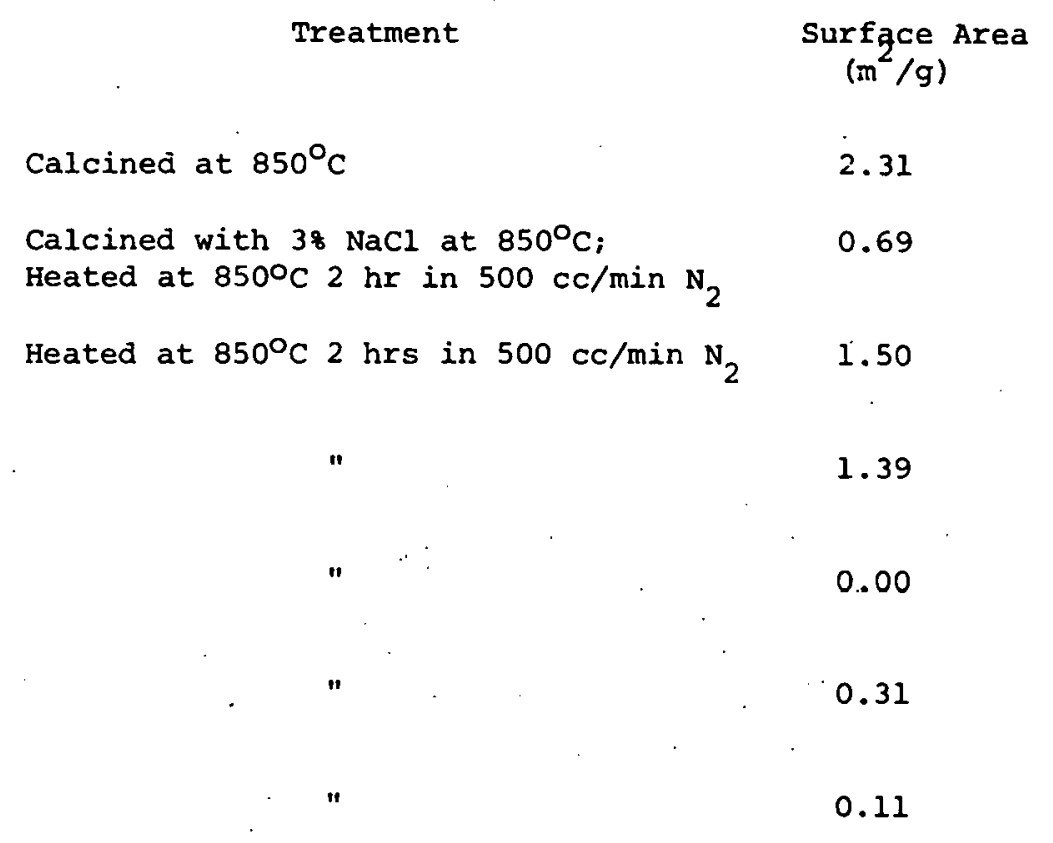




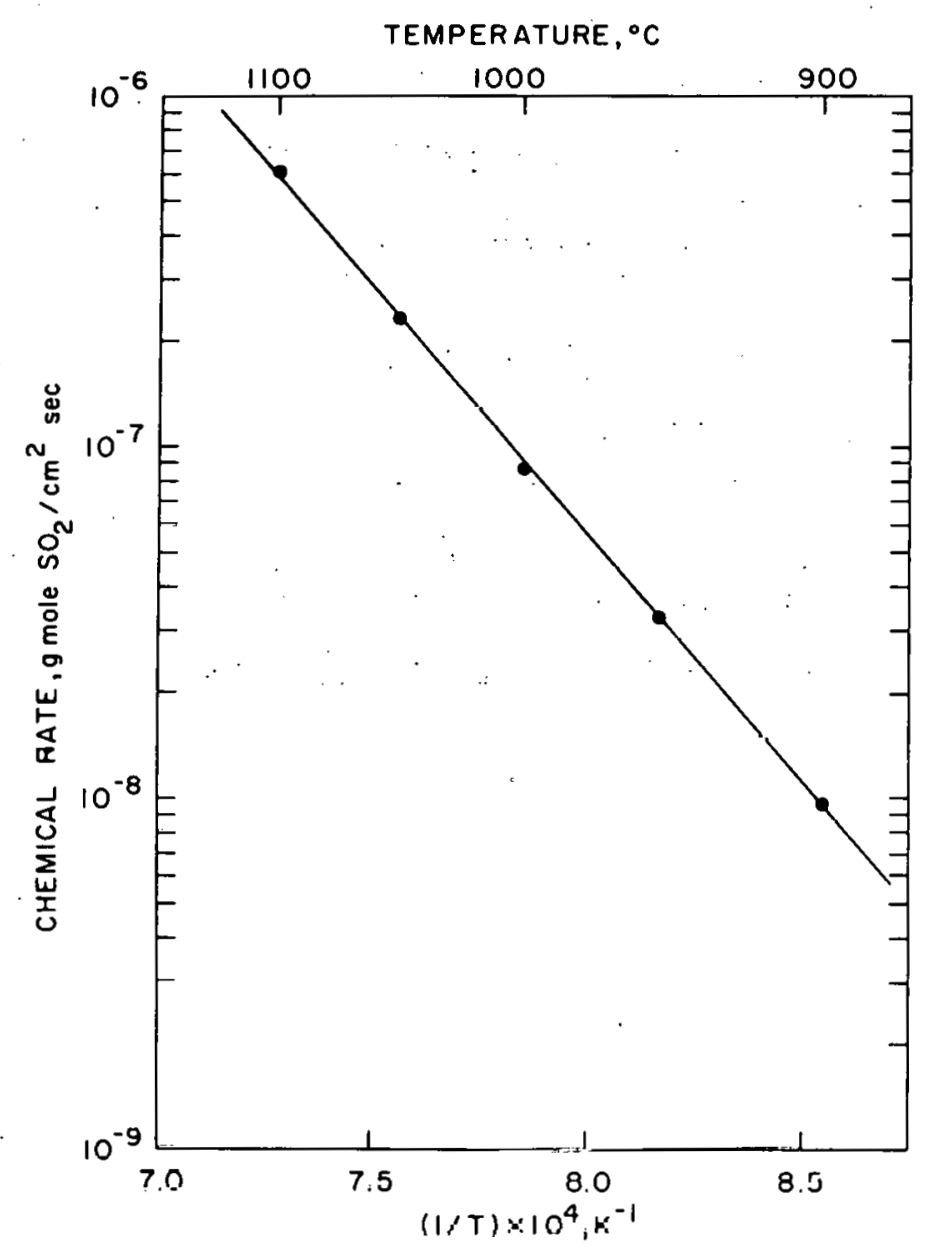

Figure 1. Rate of the reaction $3 \mathrm{CaSO}_{4}+\mathrm{CaS} \rightarrow 4 \mathrm{CaO}$ $+4 \mathrm{SO}_{2}$. $80 \%$ sulfated Greer lime ( $16 / 20$ mesh) altd coconut charcoal ( $200 / 250$ mesh) were the starting reactants. 


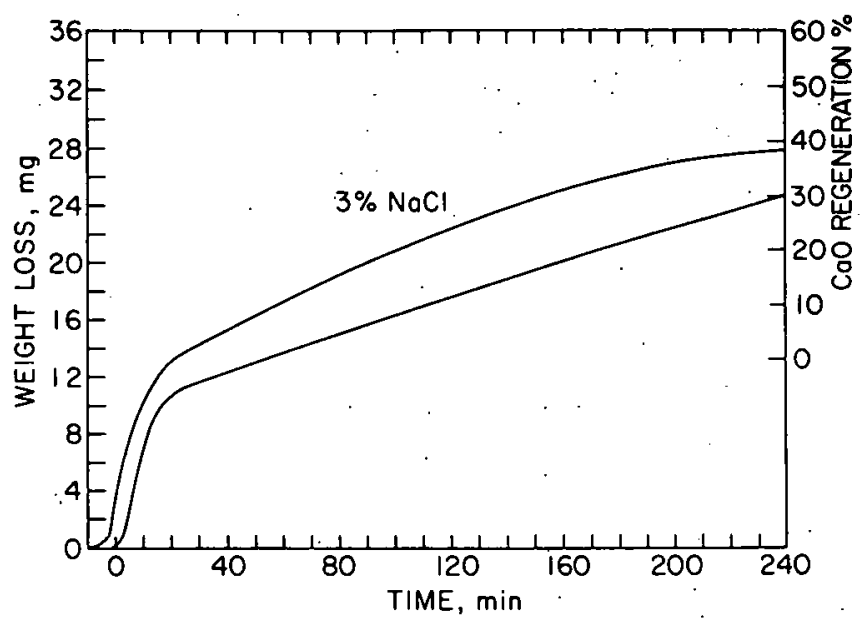

Figure 2. Rate of regeneration $\mathrm{CaSO}_{4}+1 / 2 \mathrm{C} \rightarrow \mathrm{CaO}$ $+1 / 2 \mathrm{CO}_{2}+\mathrm{SO}_{2}$ at $900^{\circ} \mathrm{C}$, with $100 \mathrm{mg} 65 \%$ sulfated Greer lime (16/20 mesh) and 3.55 mg coconut charcoal (200/250 mesh).

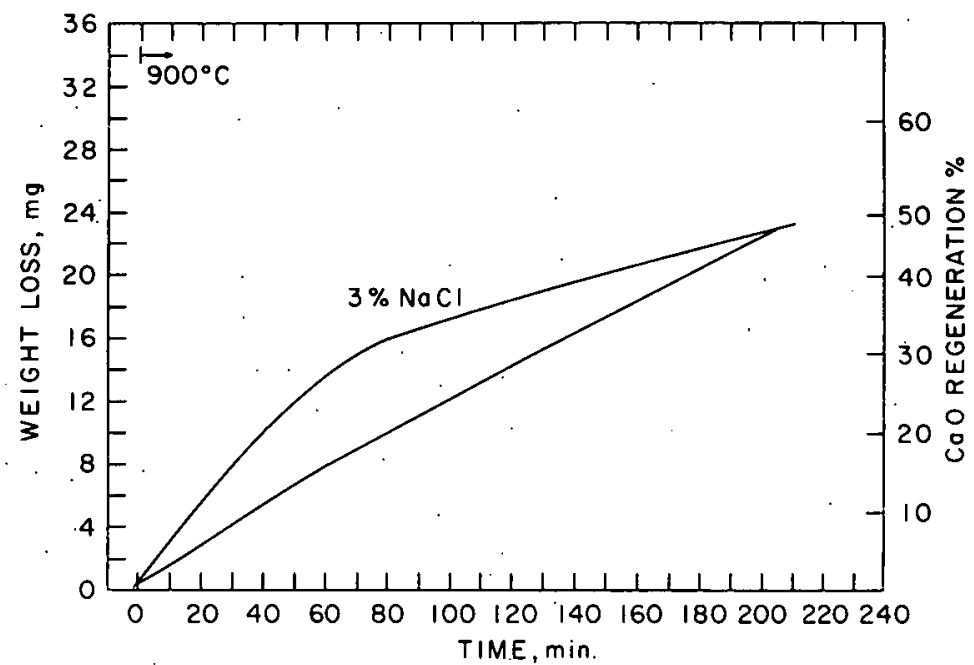

Figure 3. Rate of reaction $3 \mathrm{CaSO}_{4}+\mathrm{CaS}+4 \mathrm{SO}_{2}$ at $900^{\circ} \mathrm{C}$, with powdered.reagent grade samples. 


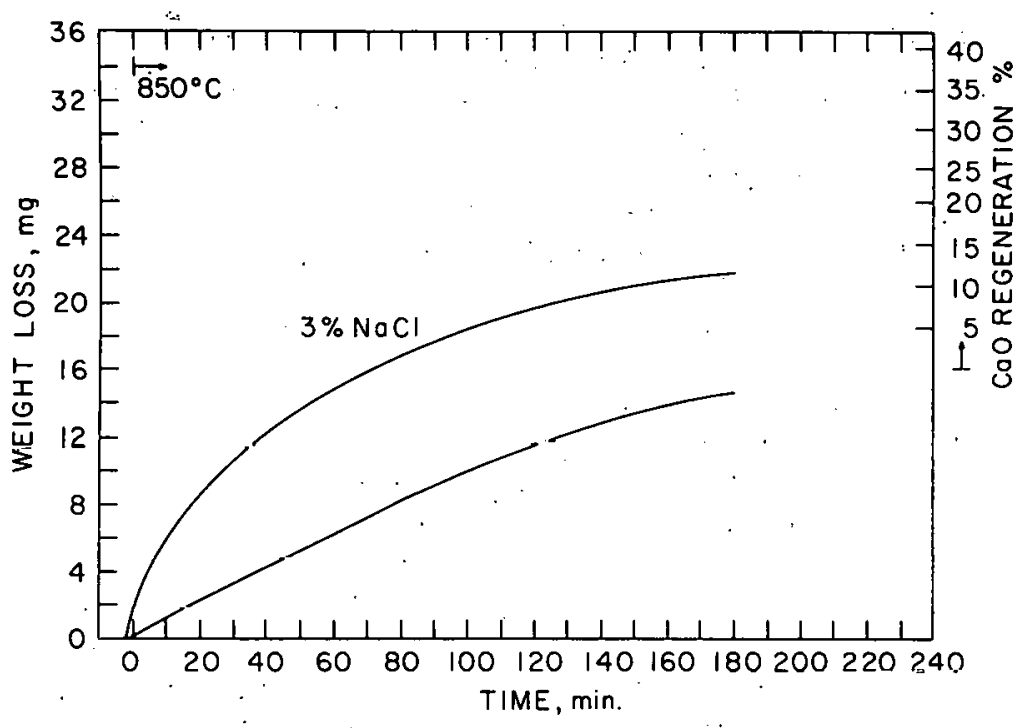

Figure 4. Rate of regeneration of $850^{\circ} \mathrm{C}$, with $100 \mathrm{mg}$ powdered reagent $\mathrm{CaSO}_{4}$ and $4.4 \mathrm{mg}$ coconut charrna1. (?nn/250 mesh).

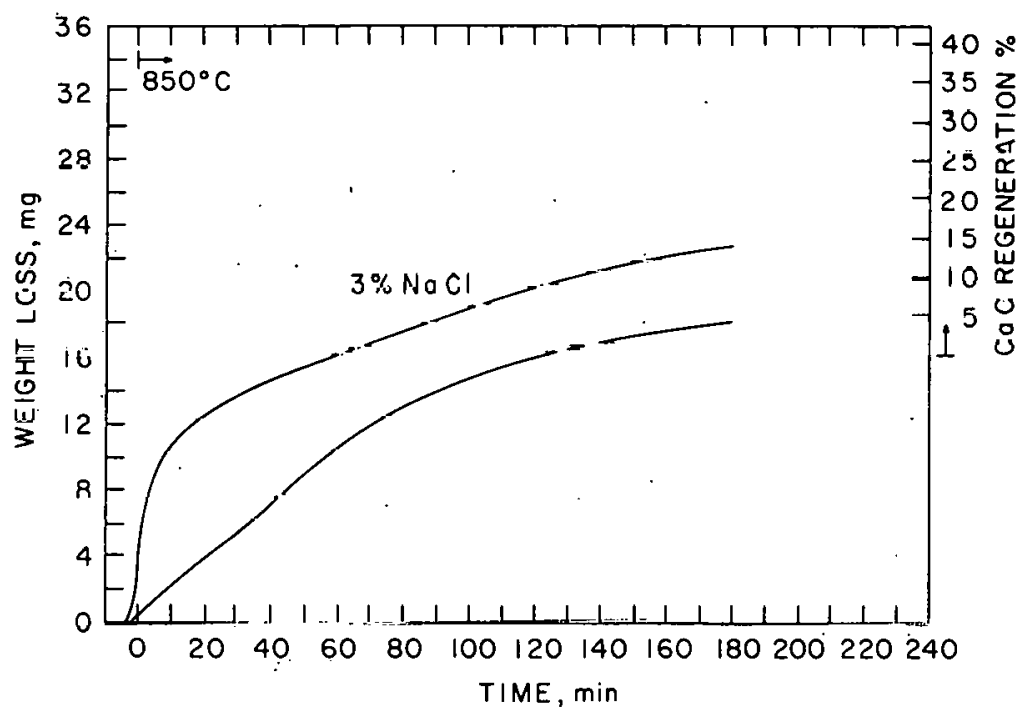

Figure 5. Rate ul segenteration at $850^{\circ} \mathrm{C}$, with $100 \mathrm{mg}$ Drierite (99.6\% $\mathrm{CaSO}_{4}, 16 / 20$ mesh) and 4.4 mg coconut charcoal (200/250 mesh). 


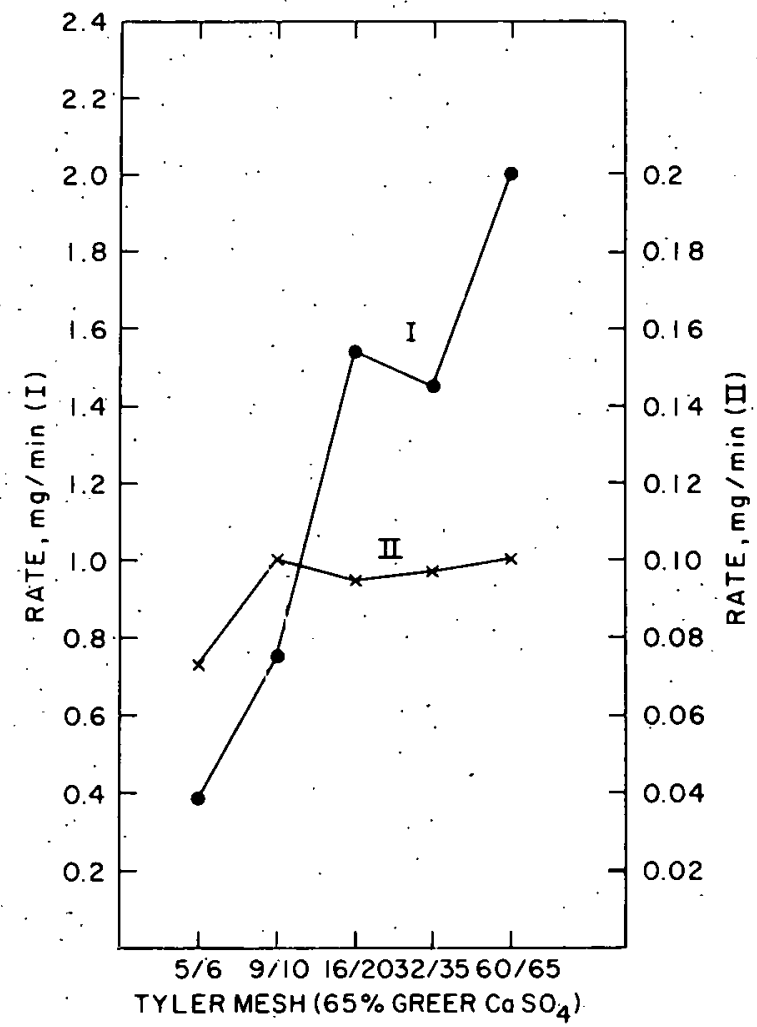

Figure 6. Effect of size of $\mathrm{CaSO}_{4}$ on regeneration at $900^{\circ} \mathrm{C}$. $100 \mathrm{mg}$ sulfated Greer lime and 3.55 mg coconut charcoal (200/250 mesh). I: $\mathrm{CaSO}_{4}$ $+2 \mathrm{C} \rightarrow \mathrm{CaS}+2 \mathrm{CO}_{2} ; \mathrm{II}: \mathrm{CaS}+3 \mathrm{CaSO}_{4} \rightarrow 4 \mathrm{CaO}$ $+4 \mathrm{SO}_{2}$.

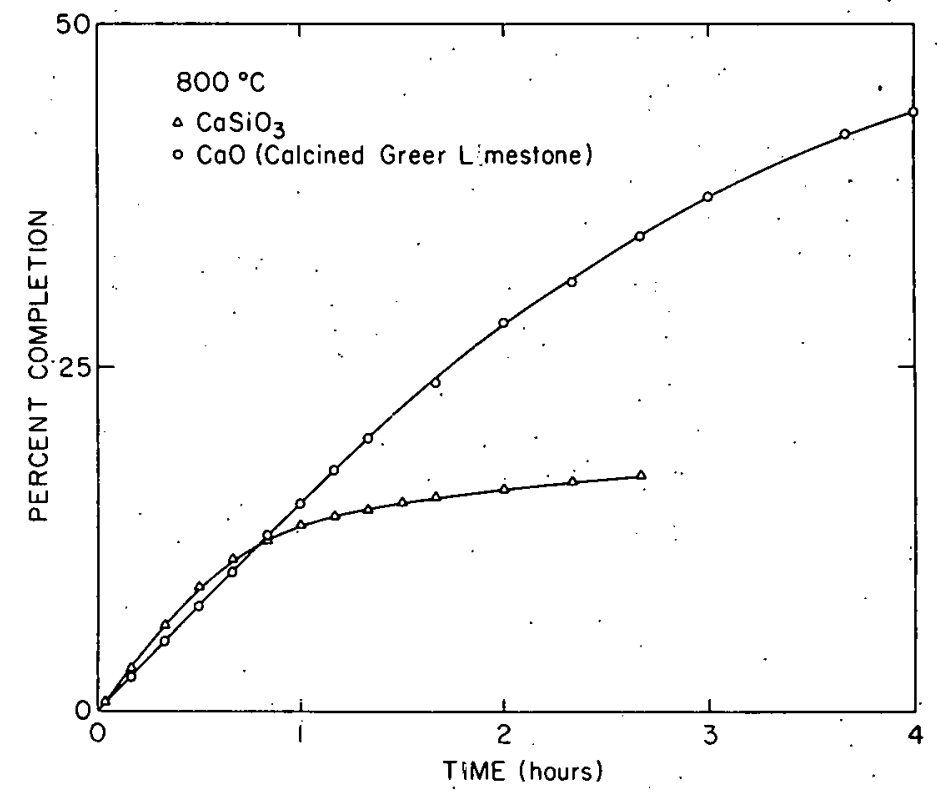

Figure 7. Comparison of rate of sulfation at $800^{\circ} \mathrm{C}$. between 16/20 mesh Greer CaO (calcined at $\left.800^{\circ} \mathrm{C}\right)$ and $16 / 20$ mesh reagent grade (99.75\%) $\mathrm{CaSiO}_{3}$ in $0.25 \% \mathrm{SO}_{2}, 5 \% \mathrm{O}_{2}$, and a balance of $\mathrm{N}_{2}$ with a total flow of 925 $\mathrm{cm}^{3} / \mathrm{min}$ at 1 atmosphere (STP). 


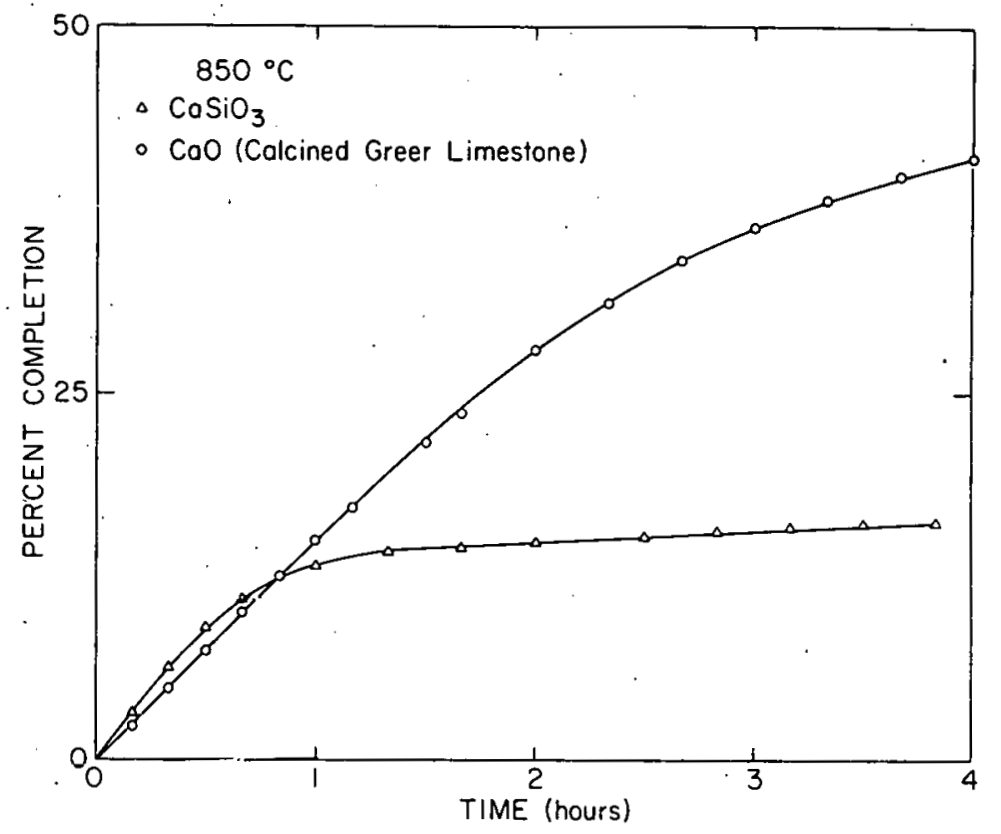

Figure 8. Comparison of rate of sulfation at $850^{\circ} \mathrm{C}$ botwocn 16/20 mesli Greèr LaO (calcined at $\left.850^{\circ} \mathrm{C}\right)$ and $16 / 20$ mesh reagent grade $\left(99.75 \%\right.$ ) CaSiO 3 , in $0.25 \% 30 \%, 5 \% \mathrm{O}_{2}$, and a balance of $\mathrm{N}_{2}$ with a total flow of 925 $\mathrm{cm}^{3} / \mathrm{min}$ at 1 atmosphere (STP).

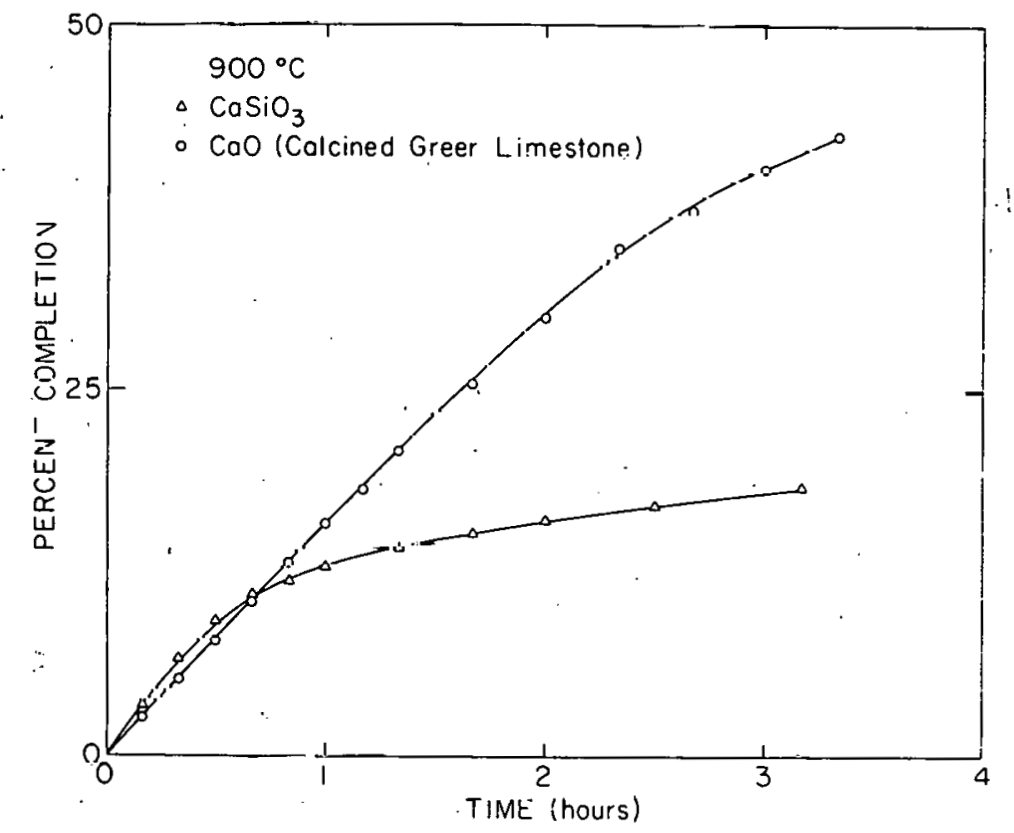

Figure 9. Comparison of rate of sulfation at $900^{\circ} \mathrm{C}$ between $16 / 20$ mesh Greer $\mathrm{CaO}$ (calcined at $900^{\circ} \mathrm{C}$ ) and $16 / 20$ mesh reagent grade. (99.75\%) $\mathrm{CaSiO}_{3}$ in $0.25 \% \mathrm{SO}_{2}, 5 \% \mathrm{O}_{2}$, and a balance of $\mathrm{N}_{2}$ with a total flow of 925 $\mathrm{cm}^{3} / \mathrm{min}$ at 1 atmosphere (STP). 


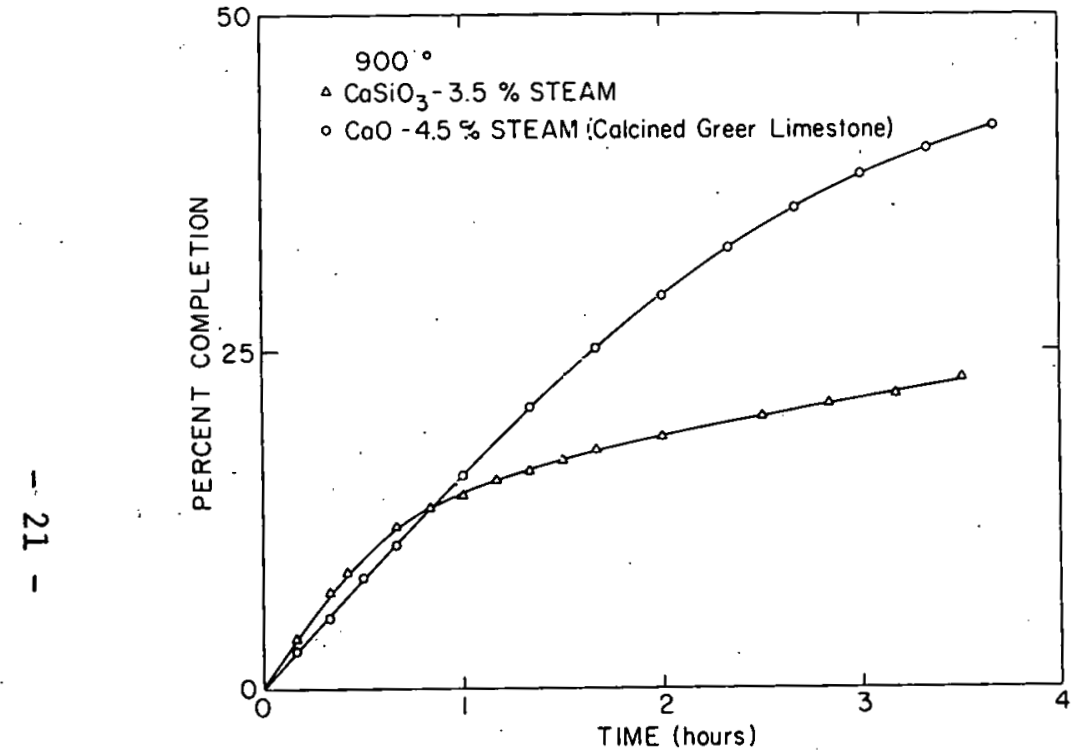

Figure 10. Comparison of rate of sulfation at $900^{\circ} \mathrm{C}$ between 16/20 mesh Greer CaO (calcined at $90 \mathrm{C}^{\circ} \mathrm{C}$ ) and $16 / 20$ mesh reagent grade (9..75\%) $\mathrm{CaSiO}_{3}$ in $0.25 \% \mathrm{SO}_{2}, .5 \% \mathrm{O}_{2}$ and balance of $\mathrm{N}_{2}$ with $\left(\mathrm{N}_{2}+\mathrm{O}_{2}\right)$ carrying a steam calcination of $3.5 \%$ for $\mathrm{CaSiO}_{3}$ and $4.5 \%$ for $\mathrm{CaO}$. Total flow was $925 \mathrm{~cm}^{3} / \mathrm{min}$ at 1 atmosphere (STP).

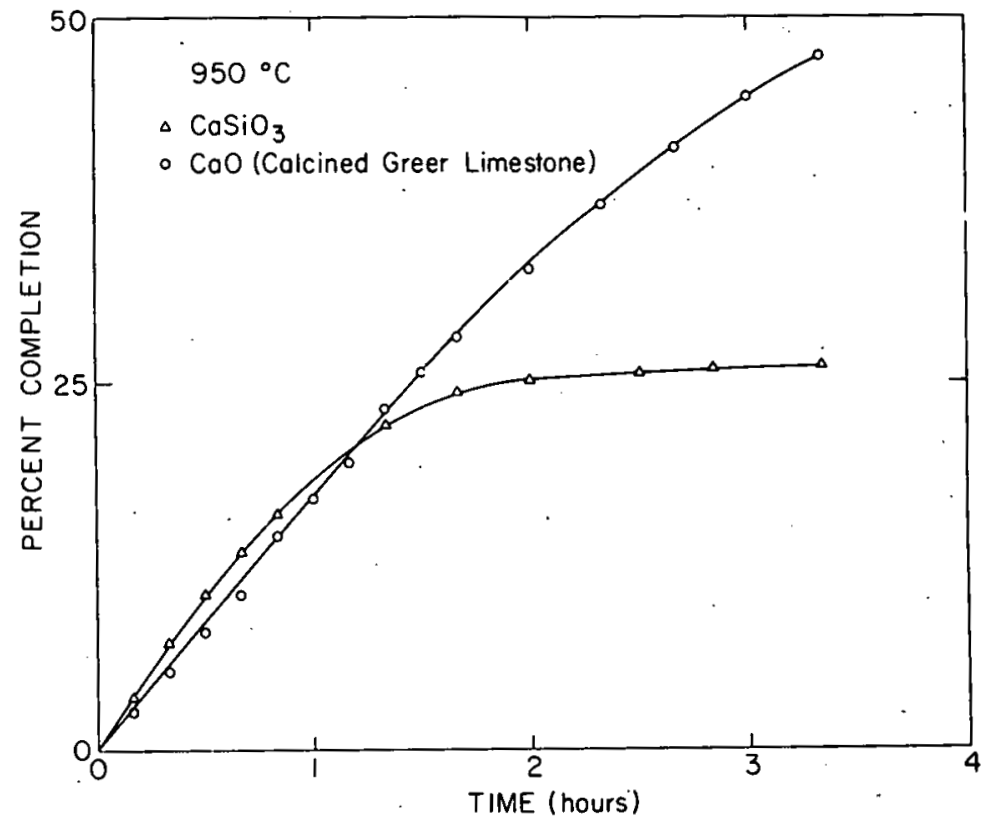

Figure 11. Comparison of rate of sulfation at $950^{\circ} \mathrm{C}$ between 16/20 mesh Greer $\mathrm{CaO}$ (calcined at $950^{\circ} \mathrm{C}$ ) and $16 / 20$ mesh reagent grade (99.75\%) $\mathrm{CaSiO}_{3}$ in $0.25 \% \mathrm{SO}_{2}, 5 \% \mathrm{O}_{2}$ and a balance of $\mathrm{N}_{2}$ for a total flow of 925 $\mathrm{cm}^{3} / \mathrm{min}$ at 1 atmosphere (STP). 


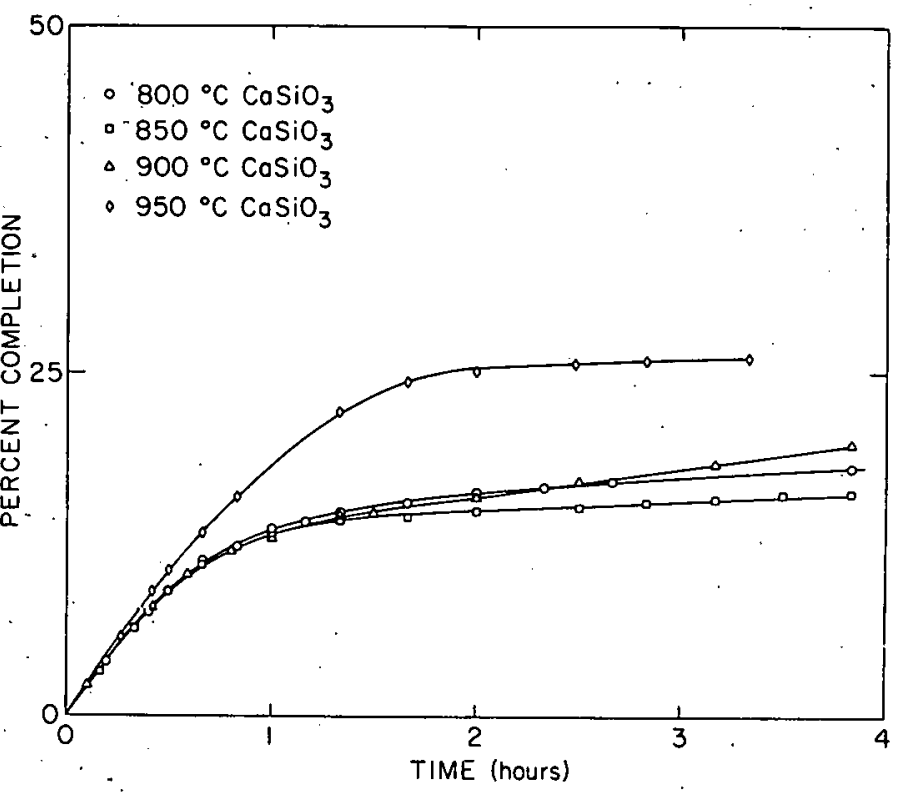

Figure 12. Comparison of rates of sulfation of $16 / 20$ mesh reagent grade $(99.75 \%) \mathrm{CaSiO}_{3}$ at temperatures of $8 \cap n^{\circ} \mathrm{C}, 850^{\circ} \mathrm{C}, 900^{\circ} \mathrm{C}$, aid $950^{\circ} \mathrm{C}$ in $0.25 \% \quad \mathrm{SO}_{2}$ and $5 \% \mathrm{O}_{2}$ and a balance of $\mathrm{N}_{2}$ in a total flow of $925 \mathrm{~cm}^{3} / \mathrm{min}$ at 1 atmosphere (STP).

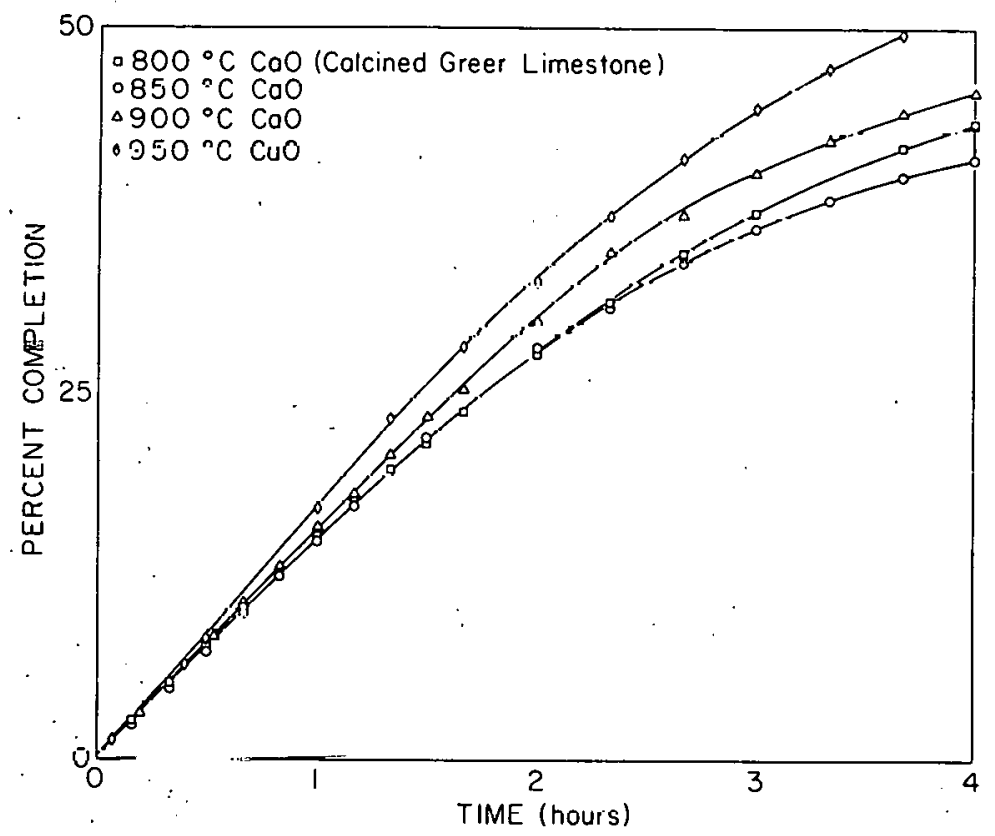

Fignre 13. Comparison of rates of sulfation of $16 / 20$ mesh Greer $\mathrm{CaO}$ (calcined temperatures 800 $950^{\circ} \mathrm{C}$ ) at temperatures of $800^{\circ} \mathrm{C}, 850^{\circ} \mathrm{C}$, $900^{\circ} \mathrm{C}$, and $950^{\circ} \mathrm{C}$ in $0.25 \% \mathrm{SO}_{2}, 5 \% \mathrm{O}_{2}$ and a balance of $\mathrm{N}_{2}$ for a total flow of 925 $\mathrm{cm}^{3} / \mathrm{min}$ at 1 atmosphere (STP). 


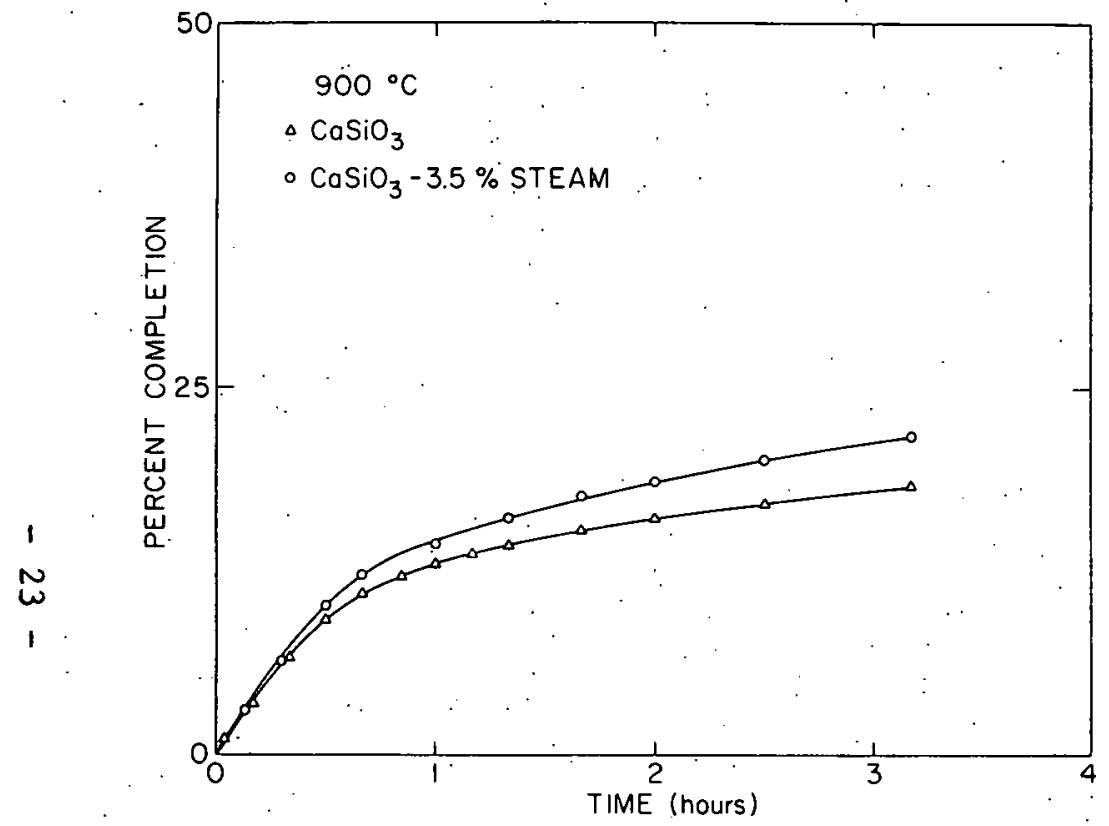

Figure 14. Comparison of rate of sulfation between $16 / 20$ mesh reagent grade $(99.75 \%) \mathrm{CaSiO}_{3}$ with $3.5 \%$ steam and without steam at $900^{\circ} \mathrm{C}$ in $0.25 \% \mathrm{SO}_{2}, 5 \% \mathrm{O}_{2}$ and a balance flow of $\mathrm{N}_{2}$ for a total flow of $925 \mathrm{~cm}^{3} /$ min at 1 atmosphere (STP) (steam carried by $\mathrm{O}_{2}$ and $\mathrm{N}_{2}$ flow).

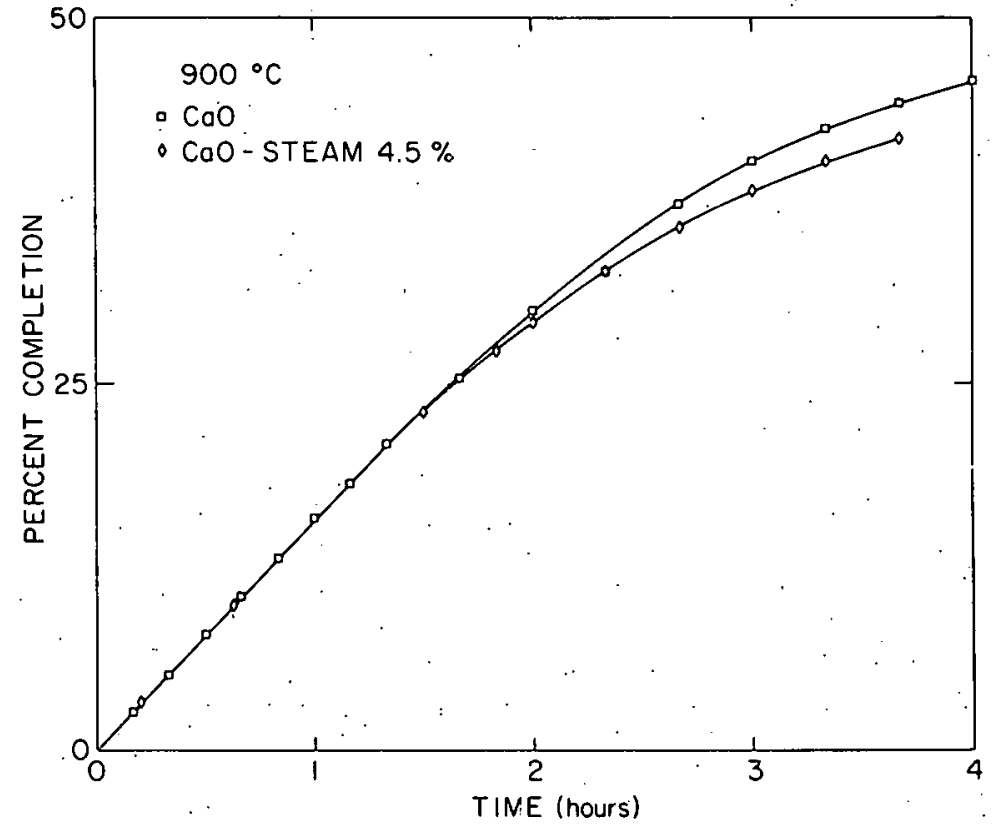

Figure 15. Comparison rate of sulfation between $16 / 20$ mesh Greer $\mathrm{CaO}$ (calcined at $900^{\circ} \mathrm{C}$ ) with $4.5 \%$ steam and without steam at $900^{\circ} \mathrm{C}$ in $0.25 \% \mathrm{SO}_{2}, 5 \% \mathrm{O}_{2}$ and a balance of $\mathrm{N}_{2}$ for a total flow of $925 \mathrm{~cm}^{3} / \mathrm{min}$ at 1 atmosphere (STP) (steam carried by $\mathrm{O}_{2}$ and $\mathrm{N}_{2}$ flow). 


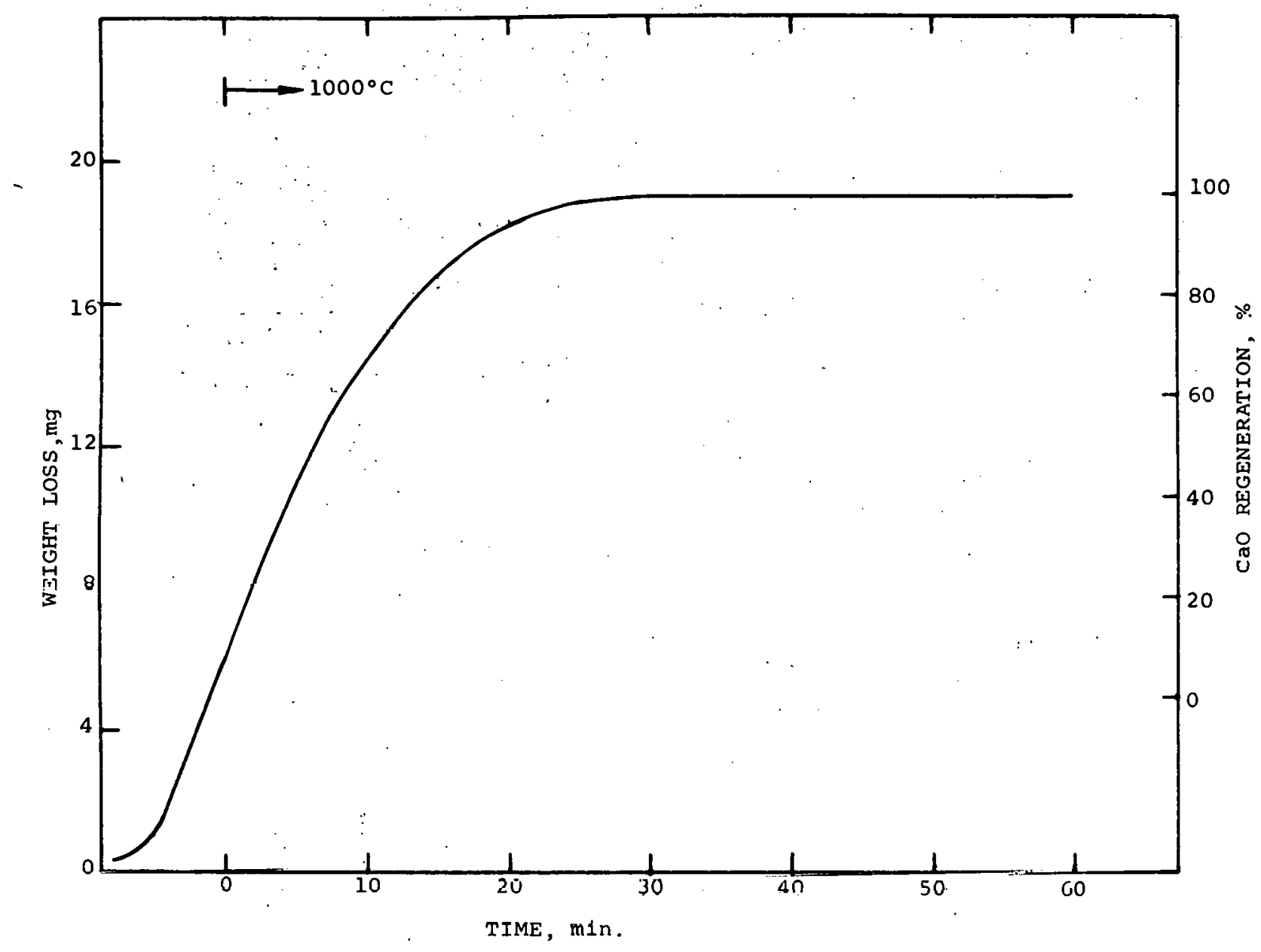

Figure 16. Rate of regeneration with coal ash at $1000^{\circ} \mathrm{C}$. $100 \mathrm{mg} 30 \%$ sulfated Greer stone from Argnnne FBC. (Sample J-11202) and $18.9 \mathrm{mg}$ Illinois No. 6 coal ash with $7 \%$ carbon $(200 / 270$ mesh $)$. 


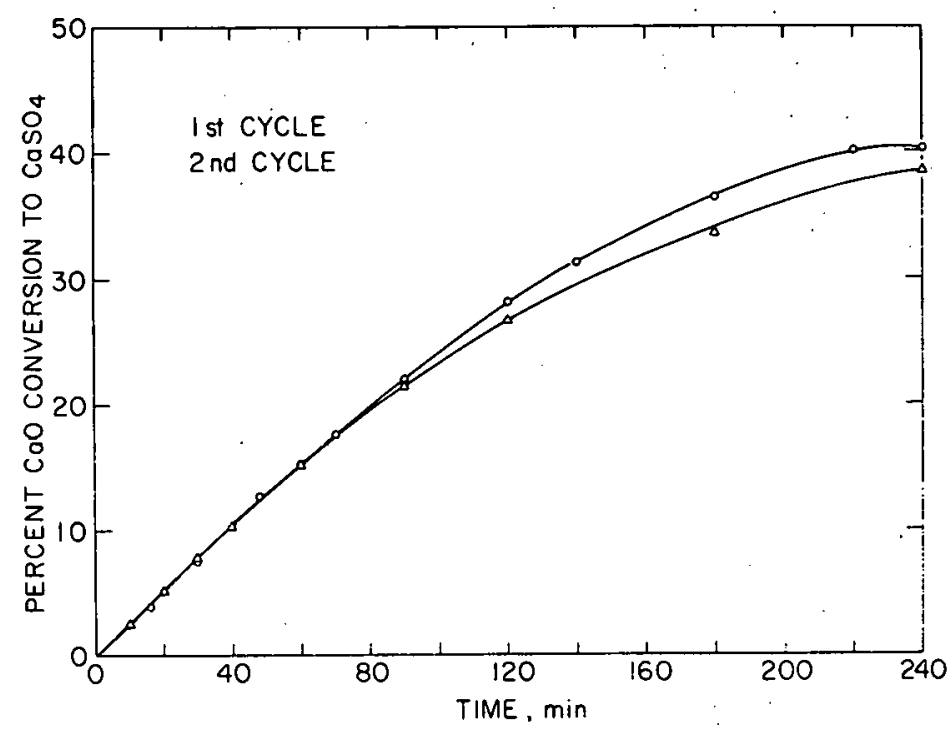

Figure 17. Sulfation rates of $95 \mathrm{mg}$ Greer $\mathrm{CaO}$ at $850^{\circ} \mathrm{C}\left(0.25 \% \mathrm{SO}_{2}\right.$ and $\left.5 \% \mathrm{O}_{2}\right)$ between 1 st cycle and the 2 nd cycle after regeneration at $950^{\circ} \mathrm{C}$ with $30.4 \mathrm{mg}$ Illinois No. 6 coal ash ( $7 \%$ carbon, 200/270 mesh).

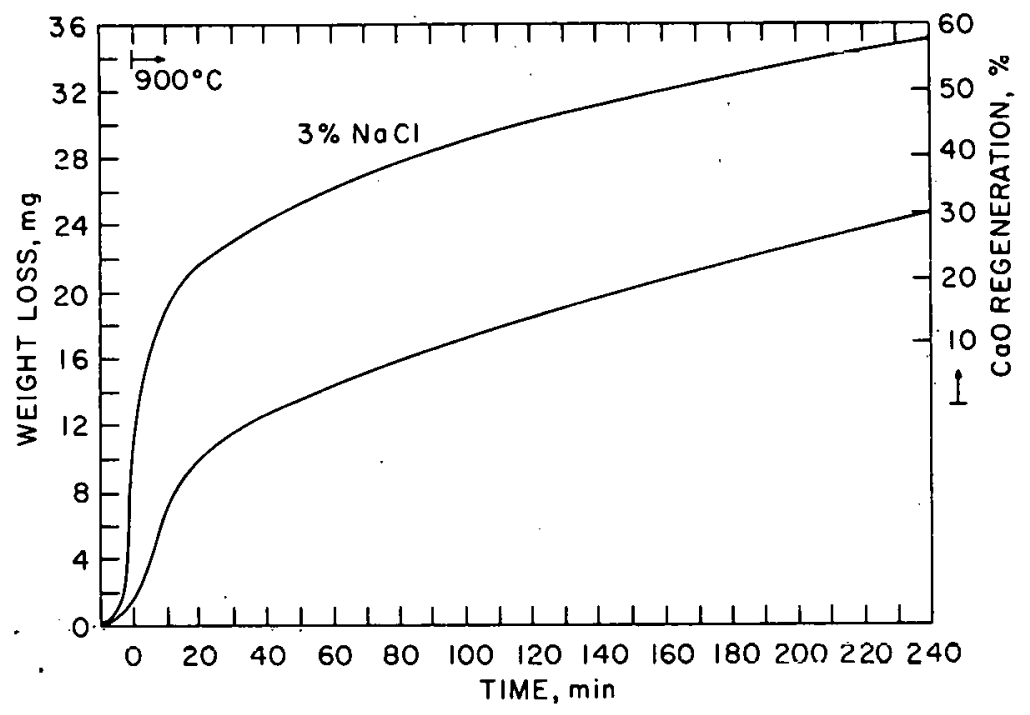

Figure 18. Rate of regeneration with coal ash at $900^{\circ} \mathrm{C}$. $100 \mathrm{mg} 65 \%$ sulfated (in TGA) Greer stone (16/20 mesh) and $41 \mathrm{mg}$ Illinois No. 6 coal ash with $7 \%$ carbon. (200/270 mesh). 


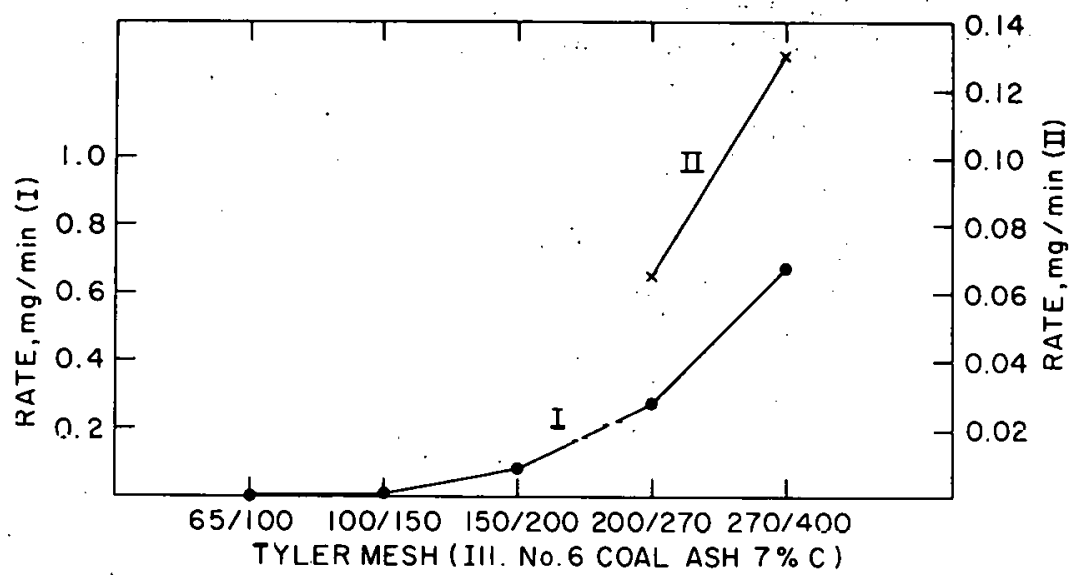

F1gure 19. Effect of size of ash on regeneration at $900^{\circ} \mathrm{C}$. $100 \mathrm{mg} 65 \%$ sulfated Greer lime $(16 / 20 \mathrm{mesh})$ and $50.7 \mathrm{mg}$ I11inois No. 6 coal ash with $7 \%$ carbon. I: $\mathrm{CaSO}_{4}+2 \mathrm{C}$

$\rightarrow \mathrm{GaS}+2 \mathrm{CO}_{2} ; \mathrm{II}: \mathrm{CaS}+3 \mathrm{CaSO}_{4} \rightarrow 4 \mathrm{CaO}$

$+4 \mathrm{SO}_{2}$.

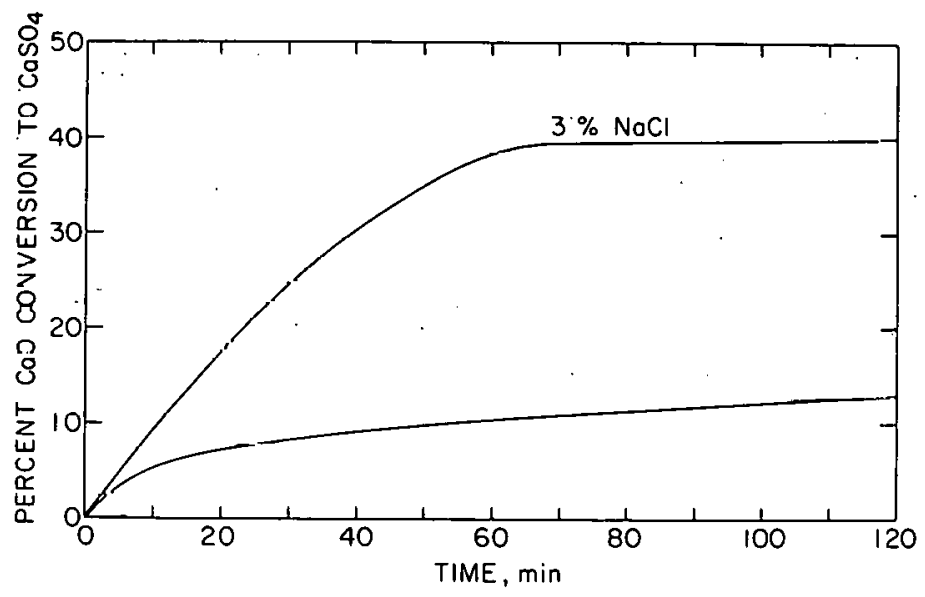

Figure 20. Sulfation rate at $800^{\circ} \mathrm{C}$, with $20 \mathrm{mg}$ powdered reagent $\mathrm{CaO}, 0.25 \% \mathrm{SO}_{2}$ and $5 \% \mathrm{O}_{2}$. 


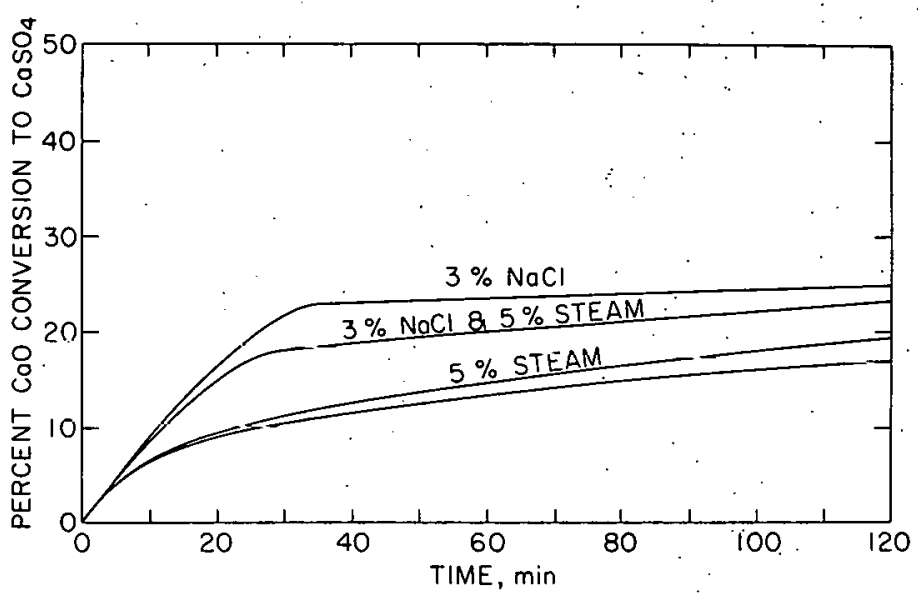

Figure 21. Sulfation rate of powdered reagent $\mathrm{CaO}$ at $850^{\circ} \mathrm{C}$, with $\mathrm{NaC} 1$ and steam.

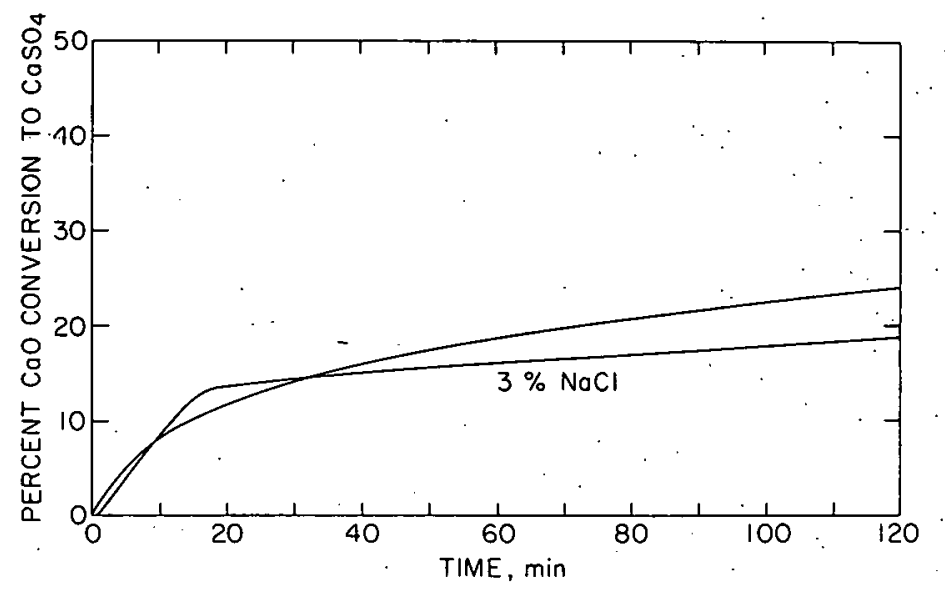

Figure 22. Sulfation rate of powdered reagent $\mathrm{CaO}$ at $900^{\circ} \mathrm{C}$. 


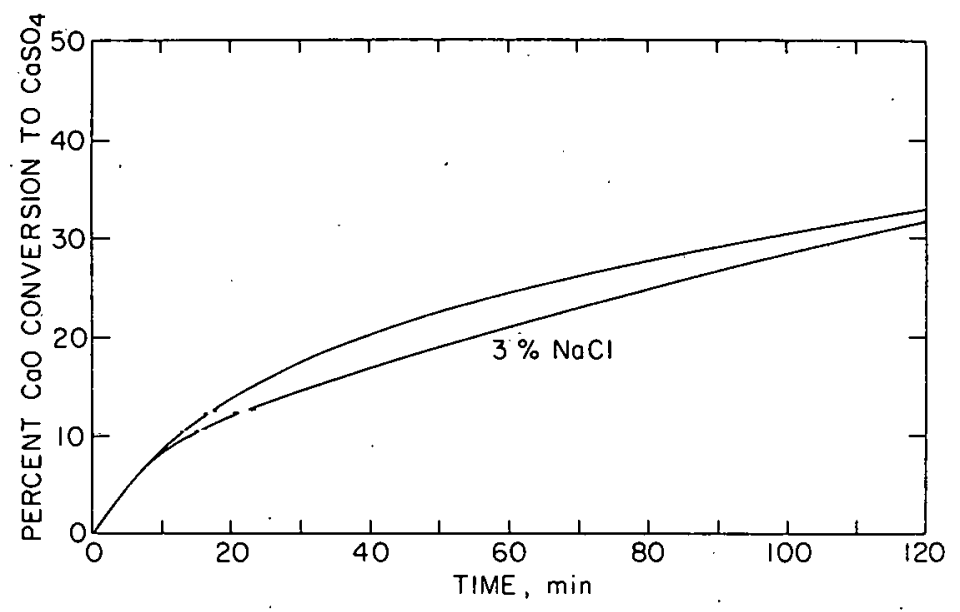

Figure 23. Sulfation rate of powdered reagent $\mathrm{CaO}$ at $950^{\circ} \mathrm{C}$.

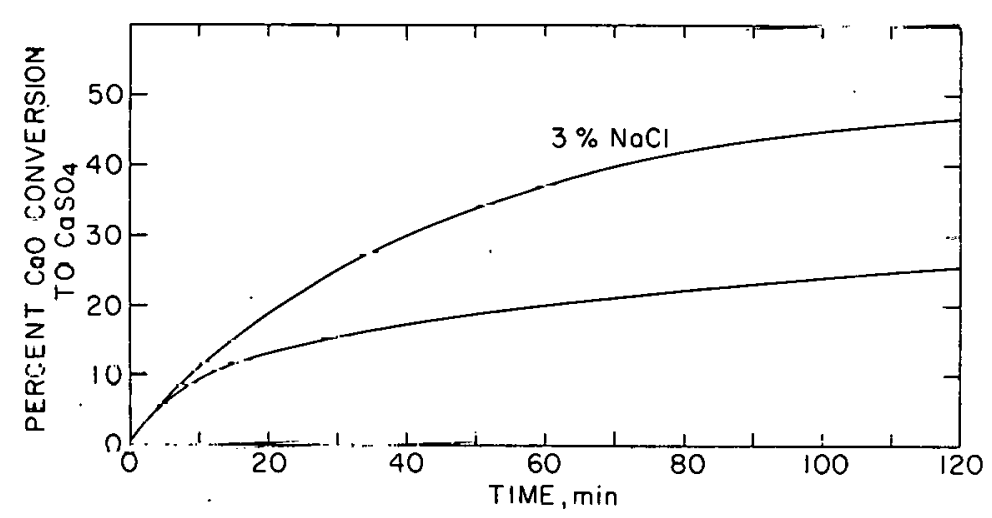

Figure 24. Sulfation rate of Greer CaO (16/20 mesh) at $850^{\circ} \mathrm{C}$. 


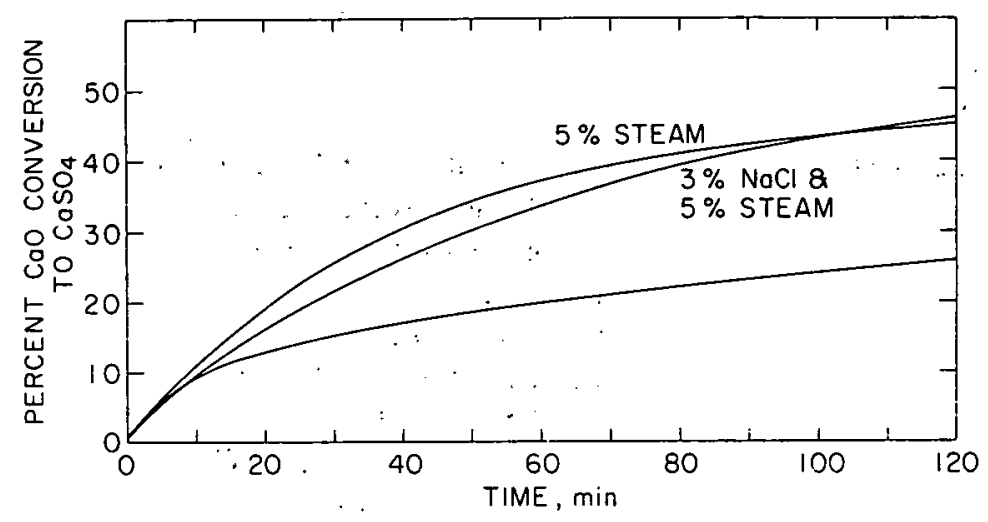

Figure 25. Sulfation rates of Greer Cao at $850^{\circ} \mathrm{C}$, with $\mathrm{NaCl}$ and steam.

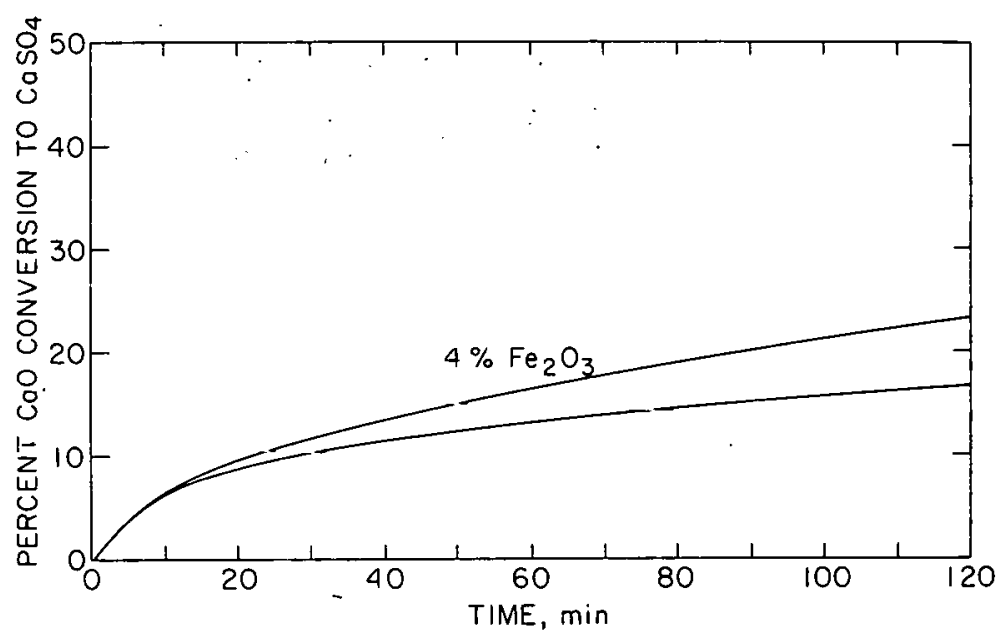

Figure 26. Sulfation rate at $900^{\circ} \mathrm{C}$, with powdered reagent grade samples.

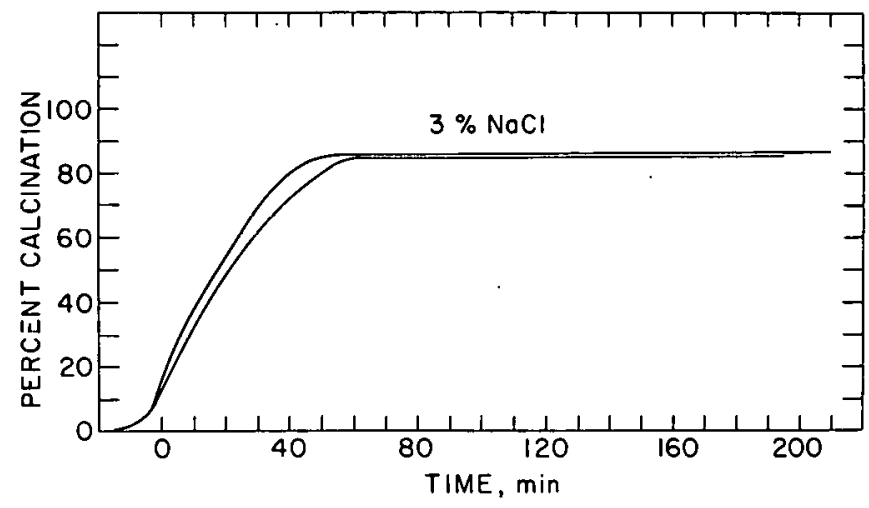

Figure 27. Calcination rate of Greer limestone at $850^{\circ} \mathrm{C}$. 
A. Macek, FE/ERDA (25)

W. E. Winsche, BNL

J. M. Hendrie, BNL

B. Manowitz, BNL

M. Steinberg, BNL

R. T. Yang, BNL (5)

N. Abuaf, BNL

A. S. Albanese, BNL

G. Farber, BNL

F. B. Kainz, BNL

C. R. Krishna, BNL

M-S. Shen, BNL

R. Smol, BNL

D. Schweller, ERDA (BNL)

D. B. Henschel, EPA

J. W. Jones, EPA

F. Princiotta, EPA

H. B. Levine, Jaycor 